[計 測 自動制 御 学 会論文集

[ Vol.54, No.9, 695/704 (2018) ]

\title{
三次元環境を移動可能な多脚型ロボット 一身体の柔軟性を利用した未知環境への適応一
}

\author{
齋 藤 明日希*·永 山 和 樹*·本 間 義 大*·青 柳 龍 志* \\ 伊 藤一 忘*大 道 武 生 ${ }^{* *} \cdot$ 芦澤 怜 史 ${ }^{* *} \cdot$ 松 野 文 俊***
}

Multi-legged Robot for 3-dimensional Environments

-Adaptive Mechanism Using Flexible Body and Legs-

Asuki Saito*, Kazuki Nagayama*, Yoshihiro Homma*, Ryushi Aoyagi*, Kazuyuki Ito*, Takeo Oомichi**, Satoshi AshizaWA ${ }^{* *}$ and Fumitoshi Matsuno***

\begin{abstract}
Maintenance and inspection of old buildings, bridges, tunnels and so on are one of the important tasks of robots, and these robots are expected to be used for search and rescue missions in case of disasters. However, in such environment, it is difficult to operate robots autonomously because the surface of them are complex and unknown. In inspection tasks, many robots are expected to be simultaneously operated by a small number of operators, therefor lack of autonomy is a serious problem for practical use. To solve this problem, we focus on flexible mechanisms of bodies of creatures, and we propose two types of multi-legged robot. One is for climbing vertical walls and the other is for climbing vertical pipes. We developed prototype robots and conducted experiments. As a result, we confirmed that the developed robot can climb autonomously by utilizing the passive mechanisms.
\end{abstract}

Key Words: multi-legged robot, wall climbing robot, pipe climbing robot, flexible mechanism, inspection of buildings

\section{1.はじめに}

日本各地においてインフラの老朽化が進み，大規模かつ広 範囲にわたる対象を迅速に点検し十分な保守作業を行なうこ とが必要とされてきている1).このような社会的要請をうけ， インフラの保守点検にロボットを活用する試みが注目される とともに，災害などの緊急時には，これらのロボットをレス キュー活動 2) 4)へ転用することが検討されている.

これらの作業では，人員不足を補うため，作業員に代わっ て，ロボットが自律的に点検作業を行なうことが期待されて おり，ロボットには非常に高い自律性が要求される。また，実 際の作業環境は, 複雑な未知構造物上を 3 次元的に移動しな がら点検を行なうことが要求される環境であり，これを実現

* 法政大学理工学部 小金井市梶野町 3-7-2

** 名城大学理工学部 名古屋市天白区塩釜口 1-501

*** 京都大学大学院工学研究科 京都市西京区京都大学桂

* Faculty of Science and Technology, Hosei University, 37-2 Kajino-cho, Koganei

** Faculty of Science and Technology, Meijo University, 1501 Shiogamaguchi, Tenpaku-ku, Nagoya

*** Graduate School of Engineering, Kyoto University, Kyotodaigakukatsura, Nishikyo-ku, Kyoto (Received October 20, 2017) (Revised May 31, 2018)
するためには，多自由度を有する高い機動性をもったロボッ トが必要とされる。しかし, 一般に, 未知で複雑な環境にお いて，多自由度ロボットを自律的に制御することはきわめて 困難であり，高度な計測制御技術が必要とされる一方で，実 際に複雑な計測装置や制御器を稼働しょうとした場合には, 計算時間の問題から実時間動作が困難となるといった問題も 生じる。したがって, インフラ点検は, 従来の「計測された データをもとに計算器内に環境のモデルを構成し，このモデ ルを用いて動作を計画して制御する」という枠組みでは，実 現が非常に難しいタスクであり，この問題を如何にして解決 するかがインフラ点検ロボットの実現における大きな課題と なっている。

一方, 生物は, 比較的知能の低い下等な生物であっても, 自 身の多自由度を巧みに動かし, 複雑な実世界で機敏かつ適応 的に振る舞うことができる。

これは, 生物は進化の過程で, 環境に適した身体を獲得し ており，脳による計算に依らず，身体と環境との相互作用に よって適応的な振る舞いを実現しているからであると考えら ており, Embodied Intelligence ${ }^{5) \sim 7)}$, morphological computation ${ }^{8) \sim 10)}$, affordance ${ }^{11) \sim 19)}$, dynamics based control ${ }^{20)}$,21)など，さまざまな分野において研究が行なわれて いる. 
しかし, 従来の生物型ロボットの研究では, 生物の運動を模 倣したものや，身体の構造を模倣したものなど，さまざまな ロボットが開発されているが，生物のもつ高い適応性の実現 には至っていない22) 30). 前者は, 位置制御系によって制御 されたアクチュエータを用いて, あらかじめ埋め込まれた運 動を再生するものが一般であり，事前に想定された環境にお いては高い性能を発揮するものの，想定された環境とは異な る環境においては上手く機能しないという問題が残っている. また，後者は，身体の構造にのみ注目したものが多く，身体 の構造と運動の生成との関係について十分に言及されていな い. 広瀬らにより提案されたソフトグリッパー ${ }^{31)}$ は，ロボッ トの構造と運動の生成との関係に言及した先駆的な研究であ り, 適応的な運動を機構的に生成することが可能な優れた機 構である。しかし，環境とロボットとの関係性については十 分に言及されていない.

われわれは，これまでの研究において，この生物の高い適 応性が如何にして実現されているかに注目し，この適応的な 振る舞いを生成する仕組みをロボットに埋め込むことで，複 雑な実環境に対応可能な多自由度ロボットの開発を行なって きた ${ }^{32) 〜 35) . ~}$

本論文では, 身体の機構, 制御器, 環境を 1 つのシステム として捉え，適応的な運動を生成する仕組みを実現するため の設計指針を示すとともに，その具体的な実現例として，イ ンフラ点検において想定される「凹凸や湾曲の存在する垂直 壁」，および，「配管，角柱などの柱状物」の 2 つの環境を考 え，実際にロボットを開発してその有用性を検証する。

\section{2. 生物の戦略}

\section{1 規則的なパターンの繰り返しと柔軟性による複雑な} 運動の生成

多脚型の生物は，脚を規則的なパターンを用いて動かすこ とで，身体の多自由度を個別に制御しょうとした場合に生じ る情報量の指数的増加による問題を回避していることが知ら れている.しかし, 各脚の詳細な動きに注目すると, 全く同 一のパターンをただ繰り返しているわけではなく，環境の状 態に応じて適応的に運動が調整されていることが確認できる. これは，脳などの中枢による集中制御ではなく，柔軟性をは じめとする身体のダイナミクスや，反射などの局所的な制御 を用いて環境との相互作用により実現されていると考えられ ている5) 22).

\section{2 環境に存在する普遍的性質の利用}

夕コは物体を把持する際，脚の根元から先端に向かって順 に脚を物体に接触させることで把持を行なっていることが報 告されている36),37).

これは，根元から順に物体と接触することで，物体の形状 に関係なく，一度物体と接触した点を移動させることなく物 体を包み込むことができるという幾何学的な性質を利用した ものであると考えられる。これによりタコは物体の形状を事 前に計測することなく把持を行なうことができる.
このほかにも, 環境の普遍的性質として動力学的性質がさ まざまな場面で利用されていることが，morphological com-

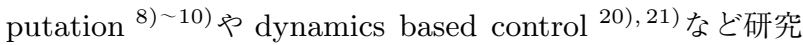
において報告されている。また，生態心理学では，環境に存

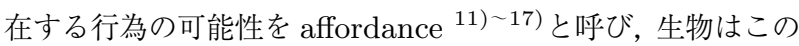
affordance を探索することでさまざまな行為を実現している と考えられている.

2.3 生物における振る舞いの生成と従来の制御系との違い 複雑な実世界では, 同じ状況が 2 度再現されることはなく, 生物は，毎回異なる状況に対して適切に振る舞っているかの ように観測される。しかし，われわれ自身の経験では，われわ れは, 毎回同じょうな状況において, 単に同じように振る舞っ ているように感じている，たとえば，毎日，靴下を履く際，各 関節の軌道レベルでは毎回異なる履き方をしている，それに もかかわらず，履き方の違いを意識することはなく，今日も いつもと同じ履き方で難なく履くことができたと認識してい る。これは，与えられた軌道を正確に繰り返すという，従来 のロボットの制御系と本質的に異なる重要な特徵である.

本論文では，この生物の運動生成における，「運動を生成す る入力のレベルでは, 毎回, 同じ戦略を繰り返しているだけ にもかかわらず，出力側の生成された運動を見ると，環境に 合わせて毎回異なる適応的な振る舞いが生成されている」と いう仕組み ${ }^{38)}$ をいかにして実現するかについて考え，同じ戦 略の繰り返しから異なる適応的な振る舞いを生成するメカニ ズムとして，実世界に存在する力学的性質などの普遍的な性 質に注目し，この普遍的な性質を利用するために，身体の受 動的な構造を利用する方法を提案する。

\section{3. 提案手法}

\section{1 設計指針}

本研究では，2 章で述べた生物の戦略をロボットの制御に 適用することで未知環境において環境を計測することなくさ まざまな環境に適応可能なロボットの実現を目指す，以下に， ロボットを実現する際の設計指針について，身体の構成と制 御方法の 2 つの観点から簡単にまとめたものを示す.

\section{身体の構成方法}

1.ロボットの身体に受動関節や柔軟リンクを用い，受動的 な運動が可能な構成とする.

2. 能動関節の駆動により身体と環境が相互作用し身体の柔 軟関節 (柔軟リンク) が受動的に運動する構成とする。

3. 柔軟関節間 (柔軟リンク間) に拘束を与え，これらが連動 して運動する構成とする。

制御方法

1. 能動関節には周期的なパターンを印加し，位置制御は行 なわない

2. 受動関節間の拘束を変化させることによりロボットと環 境からなる系のマクロ的な振る舞いを制御する.

3. ロボットのミクロ的な振る舞いは, 環境との相互作用に 
より受動的に実現される.

ロボットには，受動関節や柔軟リンクなど，環境との相互 作用により受動的に運動が生成される機構を積極的に用い, 運動の生成を環境の力学的性質に委ねることで制御系の負担 を軽減する，能動関節は, 系に力学的エネルギーを供給する ために用いられ，能動関節の運動によって受動関節が環境と 相互作用し，ロボット全体の運動が生成される。また，各受 動関節を互いに連携させ，ロボット全体として合目的な運動 が生成されるよう，各受動関節の間に力学的な拘束を与える. 能動関節の制御は, あらかじめ埋め込まれた規則的パターン を周期的に繰り返すものとし，ロボット全体の運動は，各関 節間の力学的拘束を変化させることで制御する。これにより， 従来手法の問題であった，多自由度を制御する際の制御系の 負担を大幅に軽減することが可能となる。ここで，提案する 方法と従来の設計方法との重要な相違点は, 能動関節と受動 関節の役割を明確に分け，能動関節を身体と環境からなる系 にエネルギーを注入するために用い，受動関節を環境に適し た振る舞いを生成するために用いている点である。これによ り, 各関節の角度を直接制御する必要がなくなり, 能動関節 により与えられたエネルギーを用いて受動関節が環境からの 反力により受動的に運動し，適応的な運動が生成される。能 動関節への入力レベルで見れば，毎回同じパターンを繰り返 しているだけにもかかわらず，受動関節の運動は, 環境に合 わせて毎回異なるものとなり, 2.3 節で述べた, 生物の制御 系の特徵である「適応的な運動の生成」を実現することがで きる。

本論文では，この設計指針を用いたロボットの具体例とし て，「凹凸や湾曲の存在する垂直壁を昇降するロボット」，お よび，「配管，角柱などの柱状物を昇降するロボット」の 2 つ のロボットを例に, 実際にロボットを開発してその有用性を 検証する.

\section{2 垂直壁用ロボット}

Fig. 1 Fig. 3 および Table 1 に設計指針に基づいて開 発した垂直壁用のロボット URARAKAIII の概要とその仕様 を示す.ここで, U1 から U7 は, 特徵的な機構を番号付けし たものであり，その詳細は以下で述べる.

ロボットは 6 脚からなり, 各脚の先端には吸盤が取り付け られている. 吸盤の吸着は, 外部に置かれたエアーコンプレッ サーの圧力をエジェクタを用いて負圧に変換することで実現 している．各脚は自重を支える十分な剛性を確保するための 剛体リンク機構（U6）と，壁の凹凸や湾曲に適応するための 柔軟関節 $(\mathrm{U} 2, \mathrm{U} 3, \mathrm{U} 4)$ および柔軟リンク $(\mathrm{U} 7)$ からなる.

Fig. 4 に示すように, 吸盤の先端には柔らかいスポンジ (U1) が取り付けられており，これによって壁表面の凹凸に受動的 に適応する．また，吸盤自身が非常に柔らかい蛇腹状の構造 (U2) となっていることで, 僅かな押し付ける力で, 壁の角度 に合わせて吸盤が受動的に変形する。壁と吸盤が接触し吸引 によりスポンジ（U1）および蛇腹 (U2) が圧縮されることで

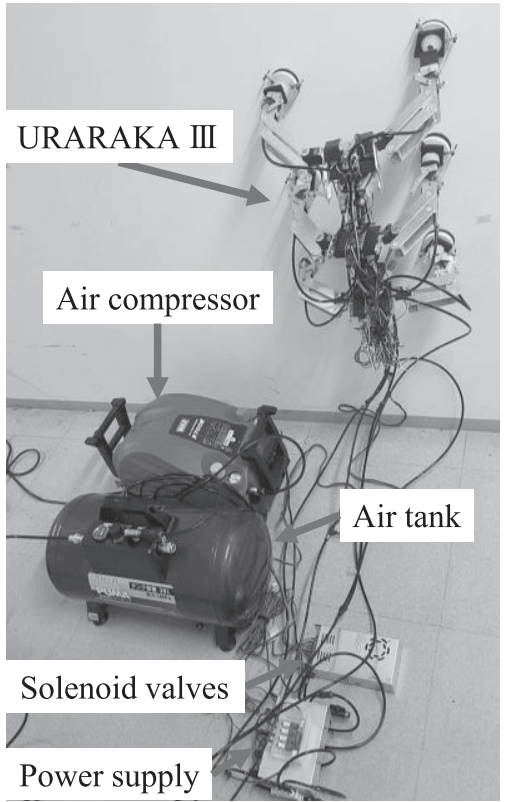

Fig. 1 Whole system

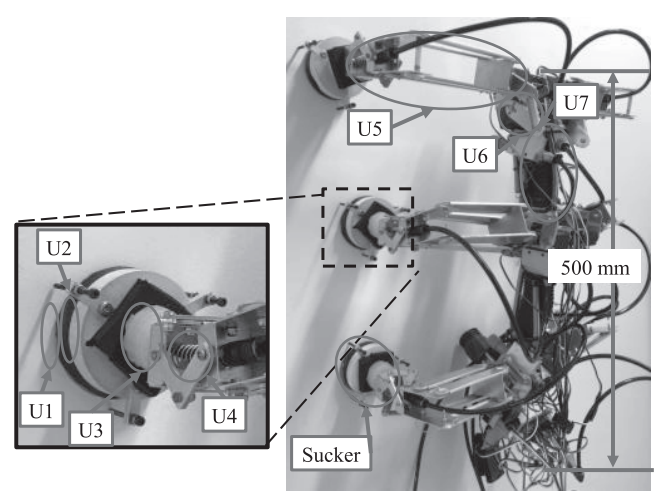

Fig. 2 Developed robot (side view)

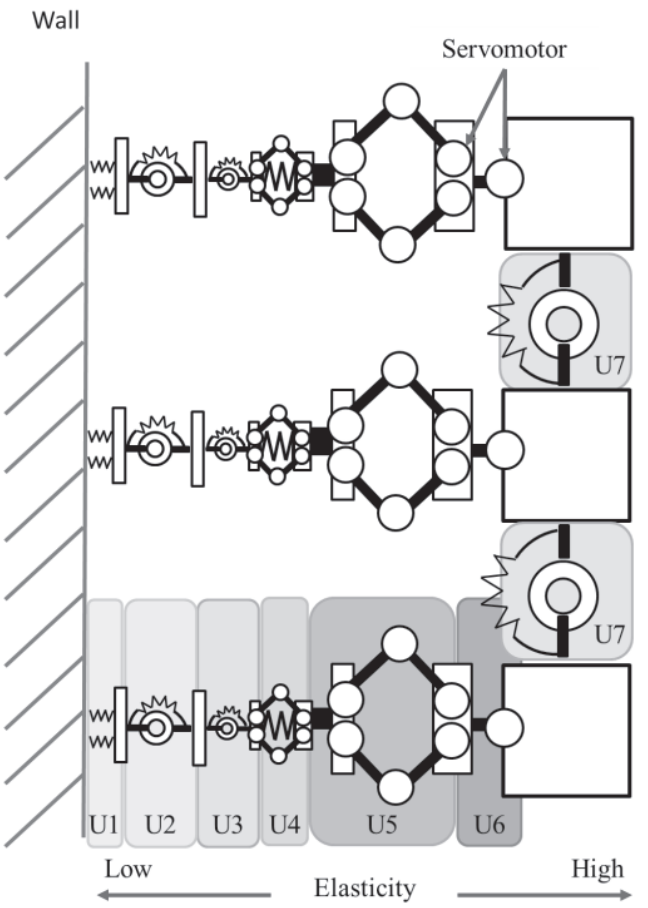

Fig. 3 Simplified mechanism of the robot (side view) 
Table 1 Specification of wall robot

\begin{tabular}{|c|c|c|}
\hline \multirow{4}{*}{ Robot } & Full length & $500 \mathrm{~mm}$ \\
\cline { 2 - 3 } & Width & $350 \mathrm{~mm}$ \\
\cline { 2 - 3 } & Height & $200 \mathrm{~mm}$ \\
\cline { 2 - 3 } & Weight & $2.1 \mathrm{~kg}$ \\
\hline \multirow{4}{*}{ Air compressor } & Power & $1.5 \mathrm{~kW}$ \\
\cline { 2 - 3 } & Discharge pressure & $\mathbf{0 . 6 9} \mathrm{MPa}$ \\
\cline { 2 - 3 } & Tank capacity & $8 \mathrm{~L}$ \\
\cline { 2 - 3 } & Weight & $14 \mathrm{~kg}$ \\
\hline \multirow{4}{*}{ Sucker } & Width & $70 \mathrm{~mm}$ \\
\cline { 2 - 3 } & Height & $35 \mathrm{~mm}$ \\
\cline { 2 - 3 } & Weight & $87 \mathrm{~g}$ \\
\hline \multirow{3}{*}{ Servomotor } & Model number & KRS-2572HV ICS \\
\cline { 2 - 3 } & Rated voltage & $12 \mathrm{~V}$ \\
\hline
\end{tabular}

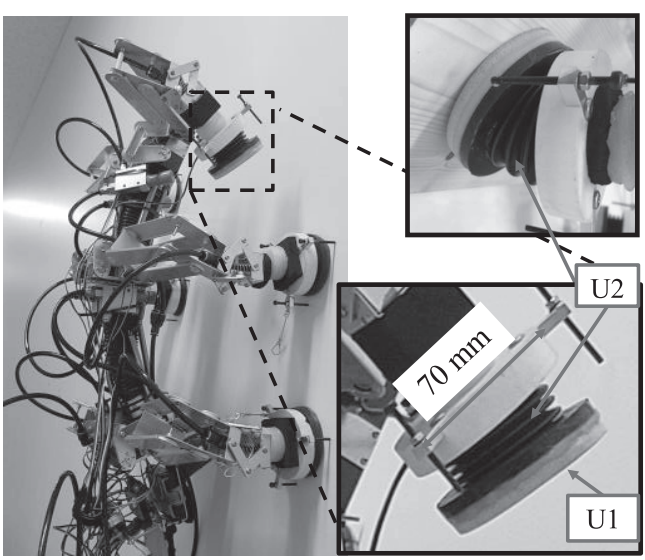

Fig. 4 Developed sucker
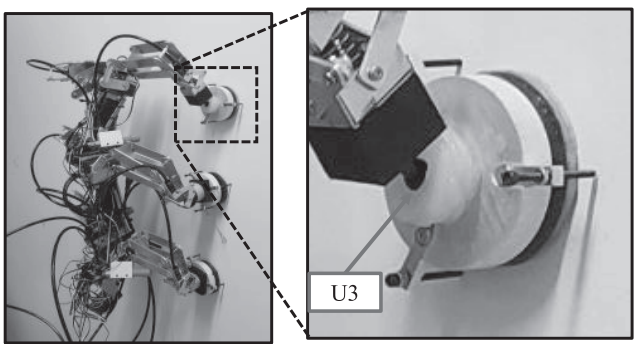

Fig. 5 Flexible joint (U3)

剛性が増加し，自重を支えることが可能となる，このとき， $\mathrm{U} 1$ および $\mathrm{U} 2$ よりも剛性の大きな柔軟関節である U3 が受動 的に回転することで，自重を支えながら，壁と脚の傾きに対 応することが可能となる (Fig. 5) 。また, Fig. 6 に示すよ うに，吸盤の周囲には， 3 点支持を行なうためのピンが取り 付けられており, 吸盤の吸着力 $F_{1}$, 吸盤の根元に加わる鉛直 下向きの力 $F_{2}$, 壁がピンを押す力 $F_{3}$, の 3 つの力が釣り合 うことで自重を支える構成になっており，壁と吸盤との間に 十分な摩擦が得られる場合には, 吸着力と鉛直下向きの力と の関係は (1) 式で表わすことができる.ここで， $r$ は吸盤の 中心から 3 点支持により構成される 3 角形の外周までの鉛直 下向き方向の距離であり,$l$ は $F_{2}$ の作用点から壁までの距離

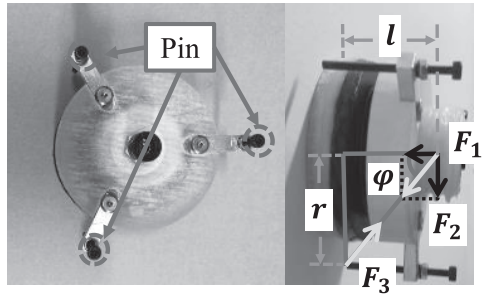

Fig. 6 Three-point mounting
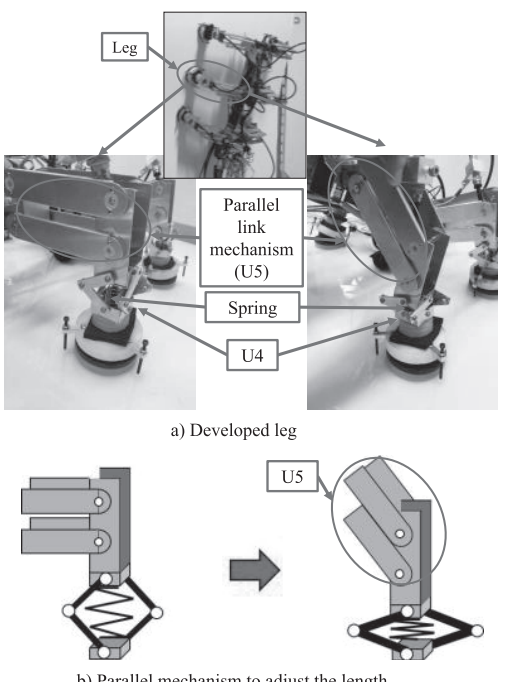

Fig. 7 Pantograph for passive adjustment of length

である.Fig. 7 に示すように，吸盤は，受動並進運動を行な うリンク機構（U4）と, 能動並進運動を行なう機構 (U5), 能動回転運動を行なう機構（U6）を介して体幹と接続されて おり，U5によって壁に押し付けられる。U4は，複数の脚が 吸着しつつ体幹が動いた際の幾何学的な拘束に受動的に対応 するためのものであり，吸盤が壁に吸着した状態で U6 を回 転させることで，体幹が昇降する．Fig. 8 に示すように，体 幹は角ジャバラと受動関節により構成された柔軟リンク構造 (U7) となっている.U8は，ねじれに対して高い剛性をもち, 左右のうち一方の脚しか接地しない場合でも, 必要な押しつ け圧を確保可能であるとともに，Fig. 8 に示すように，壁の 奥行方向に対しては柔軟性をもち，環境の湾曲に対して受動 的に適応することが可能である.

アクチュエータは U5 および U6 を駆動させるためのもの であり, 各脚が 2 つアアチュエー夕を有している (Fig. 9).

各アクチュエータは, Fig. 10 に示す周期的な運動を繰り返 し，これにより剛体リンクが運動し歩行が実現される。この 際，受動関節および柔軟リンクが環境との相互作用により受 動的に環境に適応し，環境に合わせた振る舞いが生成される.

開発したロボットでは，Fig. 3 に示すように，柔軟関節の 弾性力を, 壁に近いほうから体幹に向かって, 順に高くして いくことで，小さな凹凸から大きな湾曲まで，受動的に適応 できるような設定となっている. 

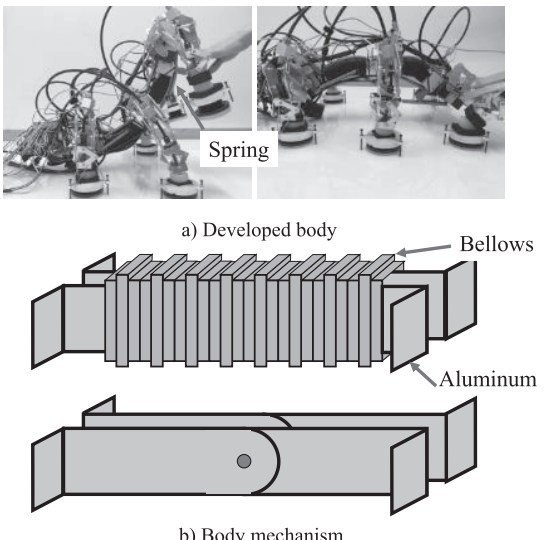

Fig. 8 Adaptation to a curved surface (U7)

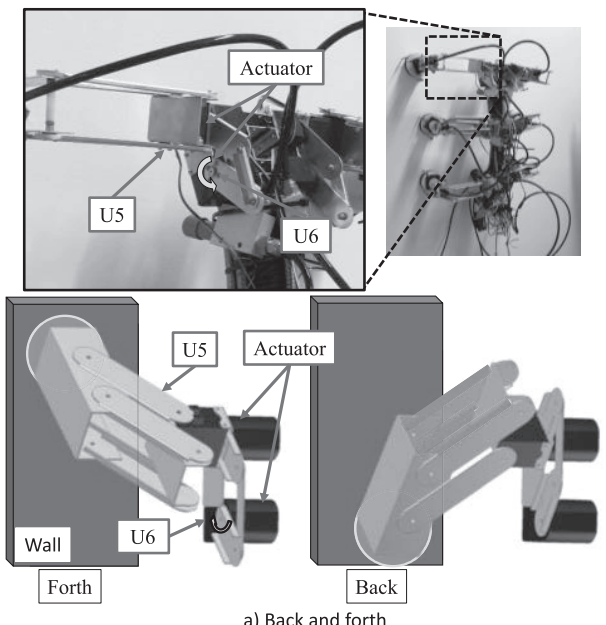

U5

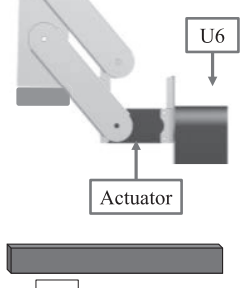

Up

Fig. 9 Movement of the legs
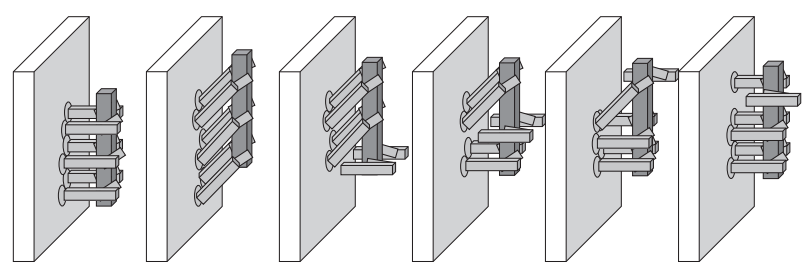

Fig. 10 Locomotion pattern (wall claiming)

\section{3 柱状物を昇降するロボット}

つぎに, Fig. 11 およびに Table 2 に設計指針に基づいて 開発した，柱状物昇降ロボット TAOYAKAII とその仕様を 示す。ここで, T1 から U4 は, 特徵的な機構を番号付けした ものであり，その詳細は以下で述べる.
Table 2 Specification of pipes robot

\begin{tabular}{|c|c|c|}
\hline \multirow{4}{*}{ robot } & Length & $521 \mathrm{~mm}$ \\
\cline { 2 - 3 } & Width & $897 \mathrm{~mm}$ \\
\cline { 2 - 3 } & Height & $178 \mathrm{~mm}$ \\
\cline { 2 - 3 } & Weight & $1.5 \mathrm{~kg}$ \\
\hline \multirow{4}{*}{ Wire winder } & Motor & RE-290 \\
\cline { 2 - 3 } & Torque & $2.3 \mathrm{~kg} \cdot \mathrm{cm}$ \\
\cline { 2 - 3 } & Gear ratio & $84: 1$ \\
\cline { 2 - 3 } & Pulley diameter & $15 \mathrm{~mm}$ \\
\hline \multirow{3}{*}{ Servo motor } & Model number & KRS-2552HV ICS \\
\cline { 2 - 3 } & Rated voltage & $12 \mathrm{~V}$ \\
\cline { 2 - 3 } & Maximum torque & $14 \mathrm{~kg} \cdot \mathrm{cm}$ \\
\hline
\end{tabular}

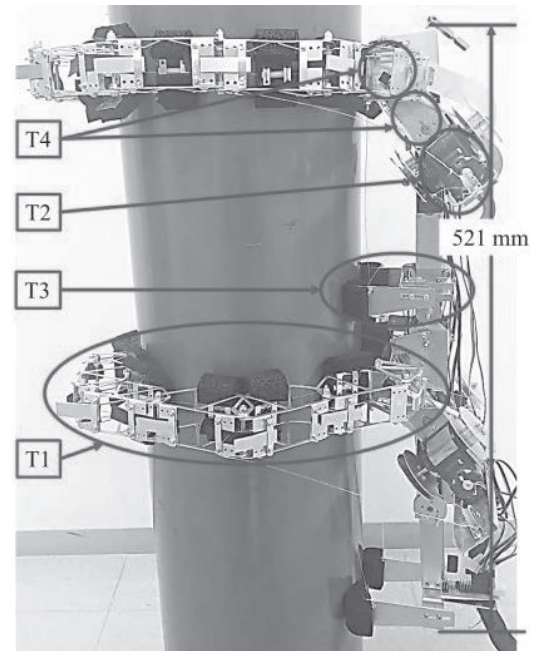

Fig. 11 Developed robot for pipes

ロボットは 4 脚からなり, 多様な形状の柱状物を把持可能 な柔軟脚 $(\mathrm{T} 1)$ が取り付けられている. Fig. 12 に示すよう に柔軟脚 $\mathrm{T} 1$ は受動関節からなる多リンク構造となっており, 脚を開くためのラバーがリンクの外側に，脚を閉じるための ワイヤーがリンクの内側に取り付けられている。受動多リン ク構造により，脚は，前後方向には関節が受動的に回転する 一方で，上下，および，ねじれ方向には高い剛性をもつ。これ により，未知形状物を受動的に把持可能であるとともに，自 重を支えるために必要な剛性が確保されている。また，ワイ ヤーを巻き取るための機構にはギア比 84:1 のウォームギア (Fig. 13) を採用しており, 一度把持すると, モータへの通電 を切った場合でもその状態が保持可能な構造となっている.

また, 物体との間に十分な摩擦を発生させるとともに, 表面 の小さな凹凸に対応するため，摩擦係数の大きなスポンジが 脚の表面に取り付けられている (Fig. $12 \mathrm{a})$ ). 脚を閉じるため

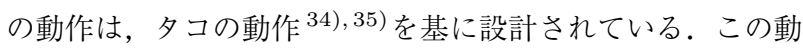
作をラバーの弾性を利用して受動的に実現するため，脚のラ バーは Fig. 12 b) に示すように, 根元から先端に向かって, ラ バーの幅を調整し，ばね定数が徐々に大きくなるように設定 されている。これにより，単にワイヤーを巻き取るという操 


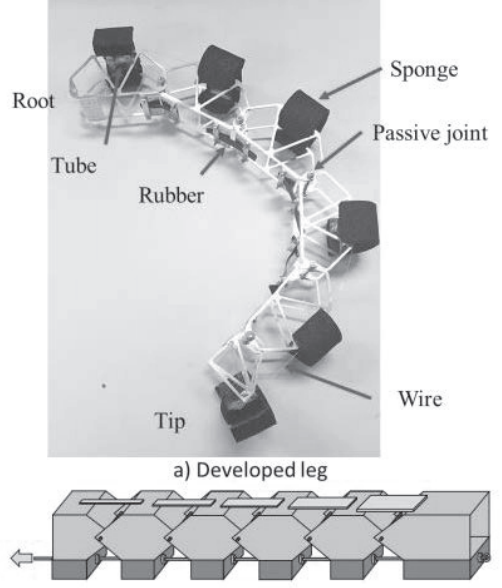

b) Width of rubber bands

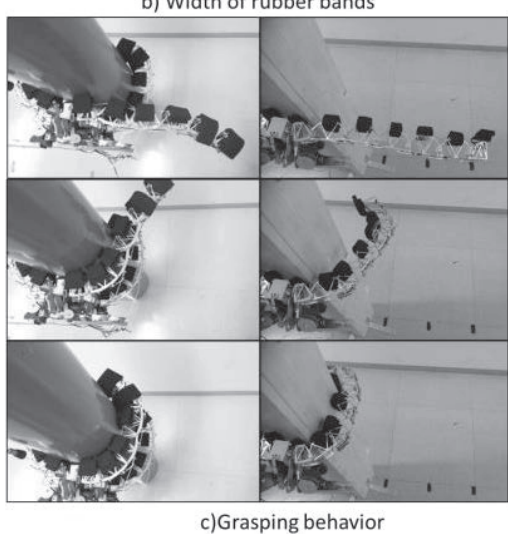

Fig. 12 Flexible leg mechanism (T1)

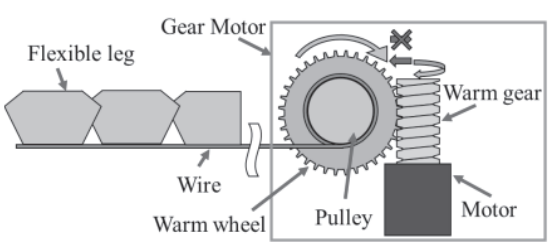

Fig. 13 Wire winder (T2)

作だけで，根元側のリンクから先頭に向けて柱状物に巻き付 きながら徐々に脚が曲がっていくという動作が実現され，柱 状物体の形状を計測することなくさまざまな形状の柱状物体 を把持することが可能となる (Fig. $12 \mathrm{c}))$. つぎに，胴体の機 構について説明する.Fig. 14 に示すように，ロボットの胴 体 (T3) は，前後方向に回転可能な受動関節を 1 つもち，受動 関節には，その可動範囲を制限するためのワイヤーと，胴体 を柱状物に押し付ける力を発生させるためのラバーが取り付 けられている。また，胴体には補助脚が取り付けられており， 上下 2 組の脚のうちどちらか一方が開いている場合でも，補 助脚が柱状物と胴体との距離を一定に保ち，胴体の姿勢を安 定させる。ロボットの昇降は根元に取り付けられた，脚を上 下させるためのアクチュエータ (T4) とワイヤーを巻き取る ためのアクチュエータ (T2)によって行なわれる (Fig. 15). ロボットの移動は，Fig. 16 に示すように，4 脚の柔軟脚が 柱状物を把持した状態で胴体を脚部が押し上げる，2，下脚を
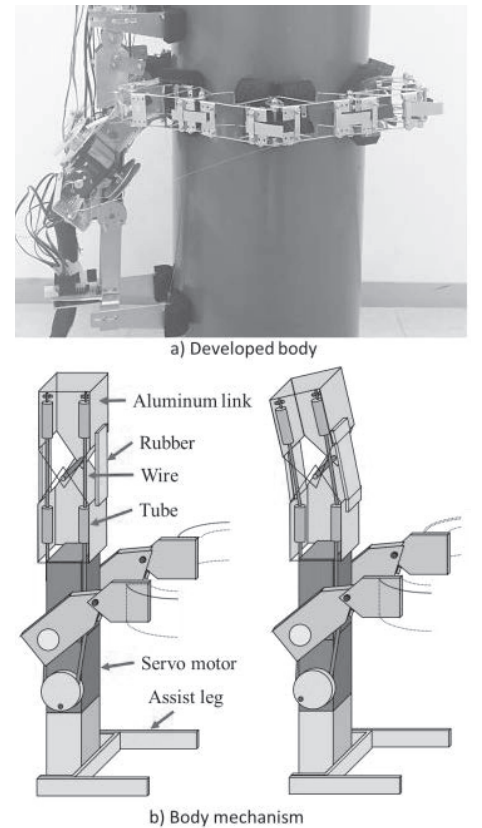

Fig. 14 Body mechanism (T3)
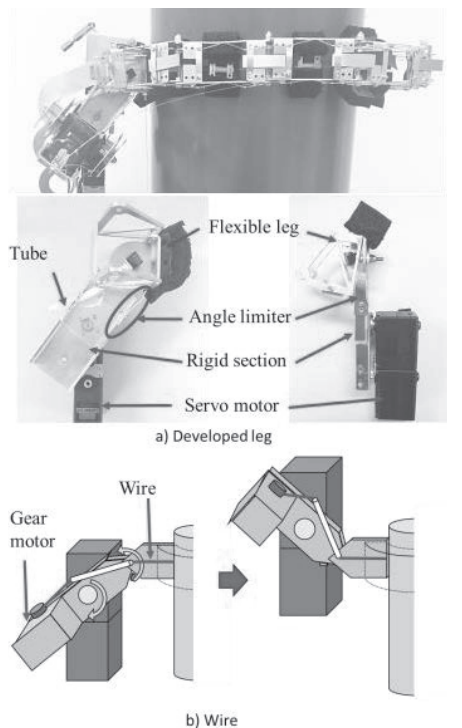

Fig. 15 Leg mechanism (T4)

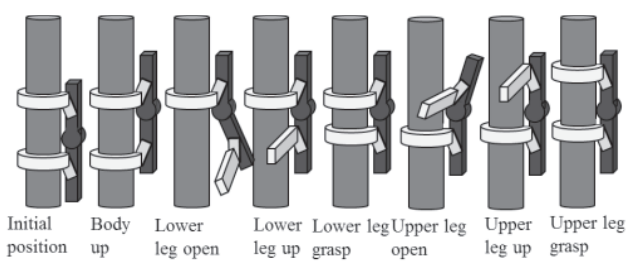

Fig. 16 Locomotion pattern (pipe claiming)

開く，3. 下脚をもち上げる，4. 下脚が柱状物を把持する， 5 . 上脚を開く，6. 上脚をもち上げる， 7 . 上脚が柱状物を 把持する，の 7 つの規則的なパターンを繰り返すことで行な う。柱状物の形状の違いに対する適応は受動的に行なわれる ため，特別な制御は必要とされず，脚を上下に動かすための 
アクチュエータと脚を開閉するためのアクチユエータを規則 的に動かすだけで，多自由度の制御が可能であり，柱状物の 形状にあった振る舞いが生成される。

また，これに加え，提案機構は，ロボットの自重が脚を物体 に押し付ける力に変換され，摩擦力となって自重を支えると いう構造となっており，電源を切った場合でも落下せず，自 重をそのまま保持することが可能である。

具体的には，脚が物体に巻き付いた状態で脚に自重が加わ ることで，物体から脚を押し広げる方向に力が伝わり，物体 と脚の間の摩擦力が増大する。また，この脚を広げようとす る力はワイヤーの張力に変換され, ウォームギアへと伝わる. しかし，ワイヤーは，ウォームギアの高ギア比によって事実 上ロックされているため動くことができず，そのままの状態 が保持され自重を支えることができる.

このように，提案機構では，先に述べた設計指針において示 したように，受動関節で構成された柔軟な脚に対して，ワイ ヤーの長さを固定するという拘束を与えることで，柔軟性に より実現される適応性を保持したまま，力のつり合いによっ て受動的に定常状態を作り出すことで，自重を支えるという 機能を実現している。また，これにより，脚を閉じるためにワ イヤーを巻き取るモー夕は，単に，脚の受動関節を物体の形 状に合わせて回転させる程度の力があればよく，自重をモー 夕の力により支える必要はないため，比較的小さなモー夕を 用いて実現可能である，以上から，高い適応性に加え，安全 性，省エネルギー性においても従来の機構に比べ優れている と考えられる。

\section{4. 実験}

最初に，凹凸や湾曲の存在する垂直壁を例に，垂直壁用口 ボットの移動性能を実験により確認する。実験環境として,

Fig. 17 に示す.タイル・木の板・湾曲したアクリル板からな る垂直壁を用いた．Fig. 18 に，タイルおよび木の板からな る壁面を移動するようすを，Fig. 19 に湾曲面を移動するよ うすを示す. Fig. 10 に示した移動パターンの一周期に要した

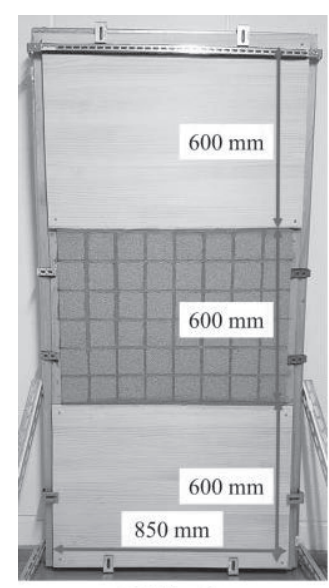

a) Tail wall

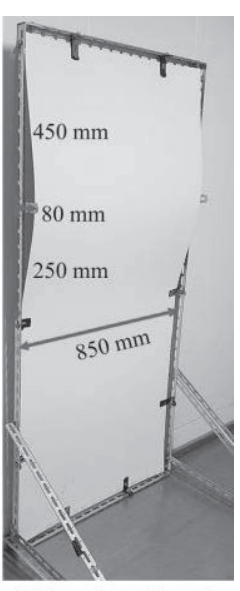

b)Curved acrylic wall
Fig. 17 Wall for the experiment
時間は約 $15 \mathrm{~s}$ であり, 移動速度は, 約 $25 \mathrm{~cm} / \mathrm{min}$ であった。 これらの結果から，身体のそれぞれの柔軟性により，小さ な凹凸から大きな湾曲に至るまで受動的に適応できているこ とが確認できる。

つぎに，柱状物を昇降するロボットの移動性能を確認する. 異なる形状の柱状物に対する適応性を確認するため, 実験環境 として, 円筒のパイプ (直径 $21.6 \mathrm{~cm}$ ), 角柱 $(16 \mathrm{~cm} \times 16 \mathrm{~cm}$ ) の 2 つの環境を用いた. Fig. 20, Fig. 21 に，円筒のパイプ および角柱を登るようすを示す. Fig. 16 に示した移動パ夕ー ンの一周期に要した時間は約 $30 \mathrm{~s}$ であり，移動速度は，約 $10 \mathrm{~cm} / \mathrm{min}$ であった。これらの結果から, 柱状物用のロボッ トについても，柱状物の形状を計測することなく，円筒と角 柱という異なる形状の物体を登ることが可能であることが確 認できる.

これらの 2 つのロボットの結果において重要な点は, 提案 手法では，ロボットの振る舞いそのものは，事前に埋め込ま
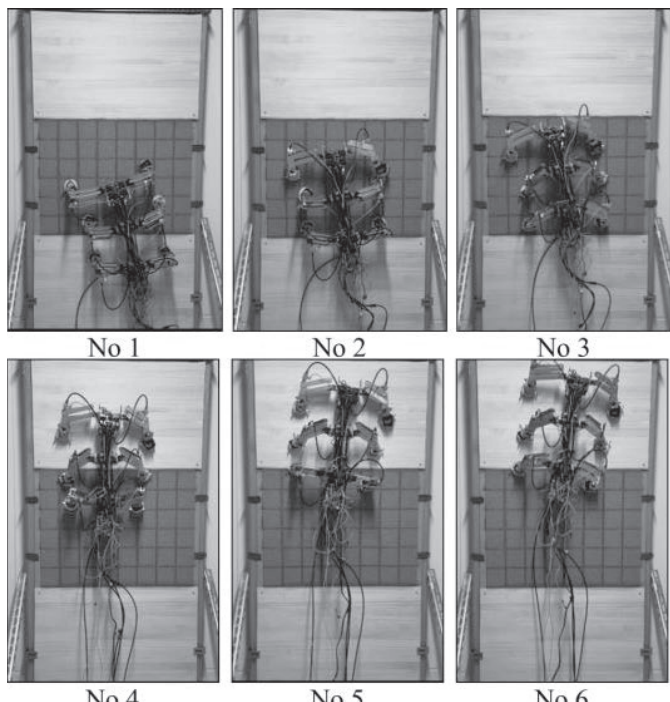

Fig. 18 Experiment result (tails and wood board)
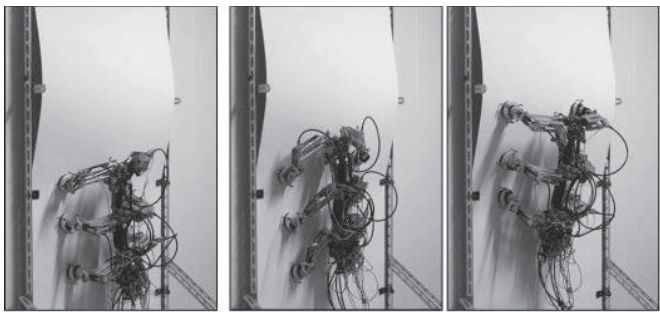

No. 1
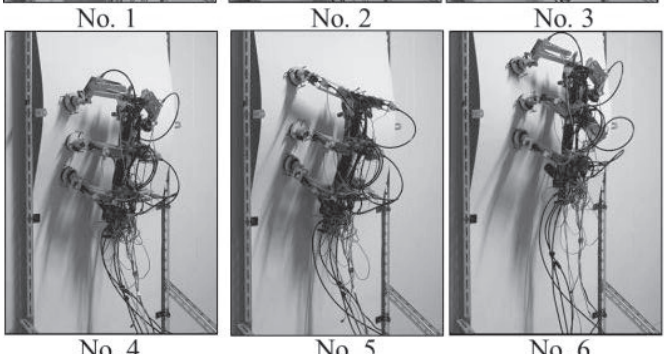

No. 4

No. 5

No. 6

Fig. 19 Experiment result (curved wall) 


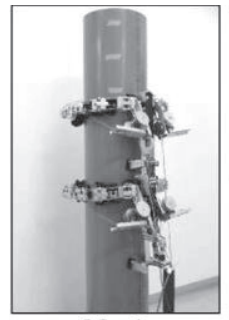

No.1

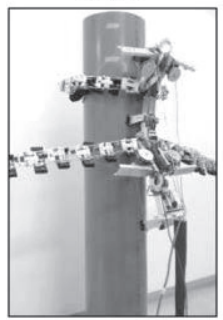

No.4

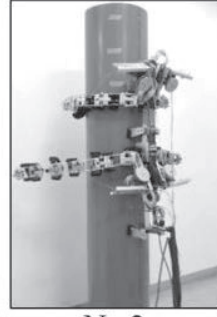

No. 2

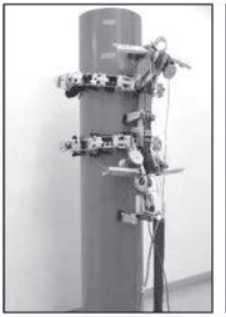

No.5

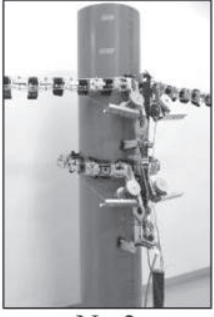

No.3

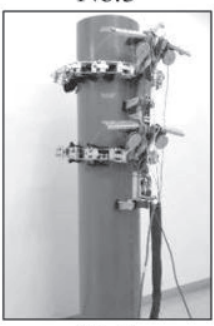

No.6
Fig. 20 Experiment result (pipe)

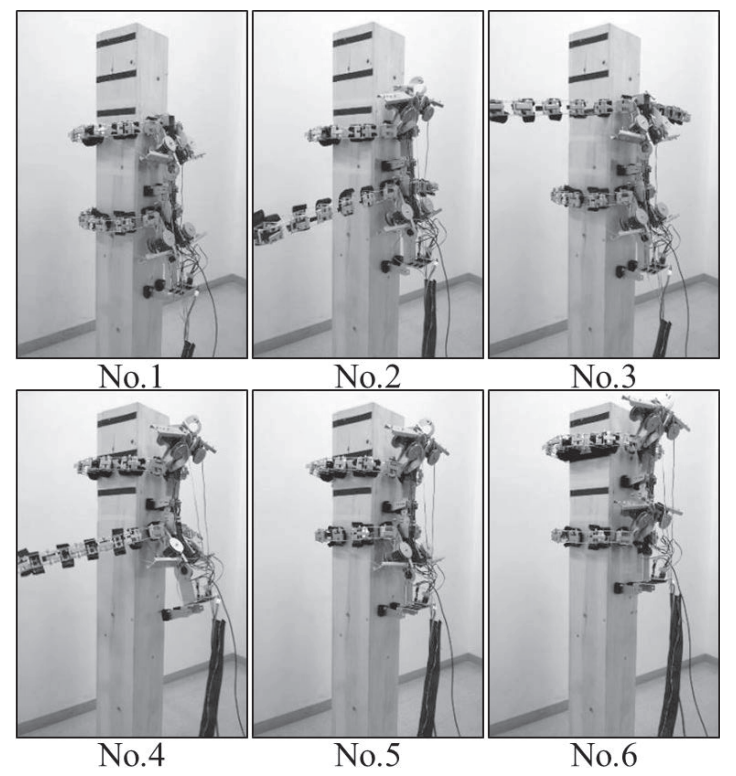

Fig. 21 Experiment result (wood pillar)

れておらず，また，環境を計測しながら環境に合わせて運動 を生成するための制御系も埋め込まれていないという点であ る。それにもかかわらず，環境に合わせた適応的な振る舞い が環境との相互作用により創発する。この仕組みにより，入 カのレベルでは，アクチュエータに対して毎回同一の規則的 なパターンを入力するだけで, 出力レベルでは適応的な振る 舞いを生成することができる。つまり，第 2 章で述べた「毎 回，同じ戦略を繰り返しているだけにもかかわらず，環境に 合わせて毎回異なる適応的な振る舞いが生成されている」と いう生物の特徴を再現できているといえる.

\section{5. 結言}

本研究では，未知で複雑な実環境において活動するロボッ トについて考え，身体の柔軟性を利用することで環境を計測
することなく，未知環境に適応可能な多脚型ロボットの開発 を目標とした。

提案した共通の設計指針に基づき，「凹凸や湾曲の存在する 垂直壁」，「配管，角柱などの柱状物」の各環境で適切に振る 舞うことが可能なロボットを提案し，実験によりその有用性 を確認した。

本研究では，さまざまな環境に適応可能なロボットを実現 するための第一段階として，それぞれの環境に特化したロボッ トの開発を行なったが，今後は，ソフトロボティクスや人工 筋肉などの技術を取り入れ，環境に応じて粘弾性および剛性 を適切に切り替え可能な身体を実現することで，これらの口 ボットを 1 つのロボットに統合し，1つの身体で複数の環境 に適応できるロボットの開発を行なっていく予定である.

謝辞 本研究の一部は, JSPS 科研費 $15 \mathrm{~K} 00316$ および $15 \mathrm{KK} 0015$ の助成を受けたものである。また，本研究の一 部は，総合科学技術・イノベーション会議により制度設計さ れた革新的研究開発推進プログラム $(\mathrm{ImPACT}) に よ り ，$ 科 学技術振興機構を通して委託されたものである.

\section{参 考 文 献}

1）藤野陽三 : 安全なインフラに向けての維持管理と SIP での取 り組み，計測と制御，55-2, 117/122 (2016)

2) R.R. Murphy: Navigational and Mission Usability in Rescue Robots，日本ロボット学会誌， 28-2, 142/146 (2010)

3) E. Rohmer, K. Ohno, T. Yoshida, K. Nagatani, E. Konayagi and S. Tadokoro: Integration of a sub-crawlers' autonomous control in Quince highly mobile rescue robot, 2010 IEEE/SICE International Symposium on System Integration (SII), 78/83 (2010)

4) H. Miyanaka, N. Wada, T. Kamegawa, N. Sato, S. Tsukui, H. Igarashi and F. Matsuno: Development of an unit type robot [KOHGA2] with stuck avoidance ability, Proceedings of IEEE International Conference on Robotics and Automation, 3877/3882 (2007)

5) R. Pfeifer, F. Iida and G. Gomez: Designing Intelligent Robots-On the Implications of Embodiment-, 日本口 ボット学会誌, 24-7, 783/790 (2006)

6）石黒章夫：知の基盤としてのしぶとさの創成，日本ロボット学 会誌, 24-7, 800/803 (2006)

7） R. Pfeifer and C. Scheier : 知の創成一身体性認知科学への招 待一, 共立出版 (2001)

8) C. Paul: Morphological Computation, Robotics and Autonomous Systems, 54-8, 619/630 (2006)

9) H. Hauser, R.M. Füchslin and R. Pfeifer, (Eds.): Opinions and Outlooks on Morphological Computation, selfpublished (2014)

10) R. Pfeifer and F. Iida: Morphological computation: Connecting body, brain, and environment, 日本学術振興会学術 月報, 58-2, 130/136 (2005)

11）佐々木正人：アフォーダンス入門一知性はどこに生まれるか, 講談社 (2008)

12）佐々木正人：アフォーダンス一新しい認知の理論，岩波書店 (1994)

13）佐々木, 三嶋：アフォーダンスと行為, 金子書房 (2001)

14）佐々木, 三嶋：アフォーダンスの構想, 東京大学出版会 (2002)

15）佐々木, 三嶋：生態心理学の構想, 東京大学出版会 (2005)

16）佐々木正人：アフォーダンス入門一若きロボット研究者の Q\&A一，日本ロボット学会誌，24-7, 776/782 (2006)

17）佐々木, 高橋, ギブソン：アフォーダンスの発見, $776 / 782$, 岩 
波書店 (2006)

18）古山宣洋: 運動を導く知覚システム, 日本ロボット学会誌, 24-7, 804/806 (2006)

19）伊藤，大須賀，石黒，古山：実世界の性質を利用した知覚と制 御，日本ロボット学会誌，24-7, 807/811 (2006)

20）有本 卓：巧みさの演出 ダイナミクスベースト制御, 日本ロ ボット学会誌，24-7, 791/796 (2006)

21）大須賀公一：ダイナミクスベースド制御の「こころ」，日本ロ ボット学会誌，24-7, 797/799 (2006)

22）広瀬茂男：へビ型ロボットの移動機構，日本ロボット学会誌, 28-2, 151/155 (2010)

23) A.J. Ijspeert: Biorobotics: Using robots to emulate and investigate agile animal locomotion, Science, 346-6206, 196/203 (2014)

24) M. Hirose and K. Ogawa: Honda humanoid robots development, Phil. Trans. R. Soc. A, 365, 11/19 (2007)

25) X. Sun, K. Hashimoto, T. Teramachi, T. Matsuzawa S. Kimura, N. Sakai, S. Hayashi, Y. Yoshida and A. Takanishi: Planning and Control of Stable Ladder Climbing Motion for the Four-limbed Robot "WAREC-1", International Conference on Intelligent Robots and Systems (IROS), 6547/6554 (2017)

26) D. Lahr, V. Orekhov, B. Lee and D. Hong: Early developments of a parallelly actuated humanoid, Saffir, Proceedings of the ASME 2013 International Design Engineering Technical Conferences and Computers and Information in Engineering Conference, DETC2013-12590 (2013)

27) H.F.N. Al-Shuka, F. Allmendinger, B. Corves and W.-H Zhu: Modeling, stability and walking pattern generators of biped robots: A review, Robotica, 32-6, 907/934 (2013)

28）茂木, 川崎, 上月, 白井, 浅野, 中西, 岡田, 稲葉: 筋骨格ヒュー マノイドにおける頸部筋群負荷を支持可能な剛性可変脊椎構造 の開発，日本ロボット学会誌，32-7,615/623 (2014)

29）亀川, 斉, 五福: 螺旋尺取り方式を用いて円柱を移動するへ ビ型ロボットの提案，計測自動制御学会論文集， 51-1，8/15 (2015)

30) M. Kaneko, T. Shirai and T. Tsuji: Hugging Walk, Proceedings of the 2000 IEEE International Conference on Robotics, 2611/2626 (2000)

31) S. Hirose and Y. Umetani: The Development of Soft Gripper for the Versatile Robot Hand, Mechanism and Mechine Theory, 13-3, 351/359 (1978)

32) K. Ito and S. Hagimori: Flexible manipulator inspired by octopus: Development of soft arms using sponge and experiment for grasping various objects, Artificial Life and Robotics, 22-3, 283/288 (2017)

33) M. Masuda and K. Ito: Semi-autonomous Centipede-like Robot with Flexible Legs, Proc. of IEEE International Symposium on Safety, Security, and Rescue Robotics 2014 (SSRR2014) (2014)

34) Y. Simodate and K. Ito: Semicircular duplexmanipulator to search narrow spaces for victims, Proc. IEEE Int. Symp. Safety, Security, and Rescue Robotics (SSRR) (2011)

35) K. Ito and Y. Simodate: Development of semi-circular duplex manipulator for search and rescue operations in narrow spaces, International Journal of Advanced Mechatronic Systems, 6-1, 1/11 (2014)

36) G. Sumbre, Y. Gutfreund, G. Fiorito, T. Flash and B. Hochner: Control of Octopus Arm Extension by a Peripheral Motor Program, Science, 293-5536, 1845/1848 (2001)

37) Y. Gutfreund, T. Flash, G. Fiorito and B. Hochner: Patterns of Arm Muscle Activation Involved in Octopus Reaching Movements, J. Neurosci, 18-15, 5976/5987 (1998)

38）伊藤, 福森 : 知覚量に基づく御系設計一蛇型ロボットの方向の
知覚量を用いたフィードバック制御一，計測自動制御学会論

文, 42-4, 436/445 (2006)

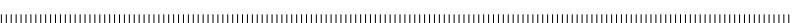

$$
\text { [著 者 紹 介] }
$$

齋 藤 明日希

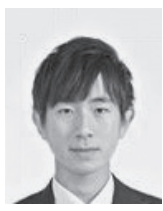

2016 年法政大学理工学部電気電子工学科卒業. 同年法政大学理工学研究科電気電子工学専攻修士 課程入学, 2018 年同課程修了, 現在に至る.

\section{永 山 和 樹}

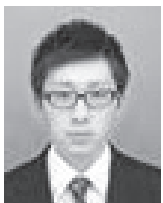

2017 年法政大学理工学部電気電子工学科卒業. 同年法政大学理工学研究科電気電子工学専攻修士 課程入学，現在に至る。

本 間 義 大

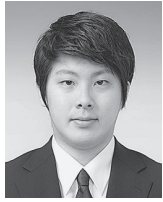

2017 年法政大学理工学部電気電子工学科卒業. 同年法政大学理工学研究科電気電子工学専攻修士 課程入学，現在に至る。

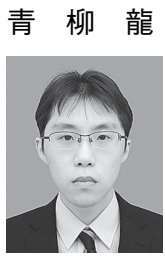

2017 年法政大学理工学部電気電子工学科卒業. 同年法政大学理工学研究科電気電子工学専攻修士 課程入学，現在に至る。

伊 藤 一 之（正会員）

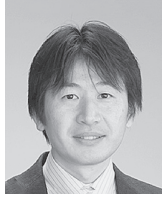

2002 年東京工業大学大学院知能システム科学 専攻博士後期課程修了, 博士 (工学). 同年岡山大 学工学部助手. 法政大学工学部専任講師を経て, 2016 年より 同大学理工学部教授. 日本ロボット学 会研究奨励賞, 船井情報科学奨励賞, 競基弘賞 (学 術業績賞) などを受賞. 主に知能ロボットに関す る研究に従事.

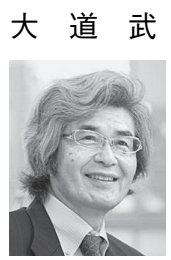

1972 年九州大学大学院工学研究科修士課程卒 業. 同年三菱重工業入社 2001 年名城大学教授, 現 在に至る．極限作業ロボットの研究に従事，近年 は社会創造ロボティクス，グリーンメカトロニク スを提唱. 博士 (工学). 
芦 澤 怜 史 (正会員)

2014 年, 名城大学理工学研究科博士課程 (機械 工学専攻) 修了. 同年, 名城大学理工学部メカトロ ニクス工学科助教, 屋外移動ロボットの研究, 解 体作業ロボットシステムの開発，吸着コンポーネ ントの開発に従事. 博士 (工学).

松 野 文 俊 (正会員・フェロー)

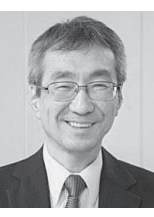

1986 年大阪大学大学院基礎工学研究科博士課 程修了. 大阪大学, 神戸大学, 東京工業大学, 電 気通信大学を経て, 2008 年から京都大学教授（機 械理工学専攻）となり, 現在に至る. 主に, ロボ ティクス・制御理論・レスキュー学に関する研究 に従事. 2005 年より NPO 国際レスキューシステ ム研究機構副会長. 93 年度システム制御情報学会 論文賞，2001，2013，2017 年度計測自動制御学 会論文賞，2001 年度同学会武田賞，2017 年度同 学会友田賞, 2013 年度情報処理学会論文賞などを 受賞. IEEE Robotics and Automation Society, Technical Committee on Safety, Security, and Rescue Robotics の Co-Chair などを歴任, 現在, システム制御情報学会会長． IEEE，日本機械学 会 (Fellow), 日本ロボット学会 (Fellow) などの会 員. 工学博士. 